\title{
A FÖLDRAJZI ÁRUJELZÓS TERMÉKEK HELYZETE A MAGYARORSZÁGI ÉLELMISZERDISZKONTOKBAN
}<smiles>[TeH4]</smiles>

THE ROLE OF GI PRODUCTS IN THE HUNGARIAN FOOD DISCOUNTERS \\ JANTYIK, LILI \\ TÖRÖK, ÁRON \\ 10 \\ Budapesti Corvinus Egyetem, Gazdálkodástudományi Kar, Vállalkozásfejlesztési Intézet, Agrárközgazdasági és Vidékfejlesztési Tanszék \\ (Corvinus University of Budapest, Department of Agricultural Economics and Rural Development) \\ 1093 Budapest, Fővám tér 8. \\ e-mail: lili.jantyik@uni-corvinus.hu
}

\begin{abstract}
(1)
More than 25 years ago, the European Union (EU) has established a sui generis system of geographical indications (GIs) for identifying the products which quality, reputation or other characteristics are linked to their geographical origin. By the end of 2018 the official register of the European Commission (the DOOR database) included 1448 registered food products with GI label, but their number is continuously increasing. For several reasons, we examined the discounters operating in Hungary in order to estimate the market size and price premium of GI foods in Hungary. Firstly, discounters' share in the Hungarian food retail sector is continuously growing and reaching the majority of the average Hungarian consumers. Secondly, their typical feature is that their supplies are almost constant and limited, discounters target the price sensitive consumers, so the minimum level of price premium can be defined here. In this study, we would like to estimate from below both the market size of Hungarian GI products and the price premium of GI products compared to their direct substitute products. To gather real life data, we have gone mystery shopping for a year every month (January-December 2018) to an Aldi, Lidl and Penny Market retail shop located in Budapest. We collected data of available GI products and their closest substitute products which were available in the shop and then we analysed the dataset consist of several hundreds of observations. Our results show that the number of GI products available in the Hungarian discounters is very limited, however, their supply is quite permanent. The majority of GI foods available in Hungarian discounters are Italian and the average price premium was around 43\% with remarkable differences. Our results show that currently GI food products have limited importance in the Hungarian food market as they are rarely available. On the other hand, a real price premium for GI products exists in the Hungarian market and an even higher price premium might be expected in less low-price oriented food retailers.
\end{abstract}

KuLCSSZAVAK: földrajzi árujelző, árprémium, piacméret, élelmiszerdiszkont, Magyarország

JEL-KóDoK (JEL CODES): M31, M37, O13, O34, Q13

DOI: https://doi.org/10.20494/TM/7/1/1
KEYWORDS: geographical indication, price premium, market size, food discounter, Hungary 


\section{BEVEZETÉS - INTRODUCTION}

Az élelmiszerek minőségét jelentős mértékben meghatározza azok termelésének, előállításának helyszíne, ami bizonyos esetekben a termékek reputációját is biztosítja. Ezt a kötődést a világ szinte minden részén elismerik és szabályozzák is, mint szellemi tulajdont. Az Európai Uniónak van globálisan is a legmeghatározóbb eredetvédelmi rendszere, amely 1992 óta közösségi szinten határozza meg a földrajzi árujelzők rendszerét önálló szabályozási (sui generis) keretek között. Az európai földrajzi árujelzős rendszer kétféle terméket különböztet meg: oltalom alatt álló eredetmegjelölésú (OEM) termékeket, illetve az oltalom alatt álló földrajzi jelzésű (OFJ) termékeket. Előbbiek magas minősége annak köszönhető, hogy előállításuk teljes egészében egy adott földrajzi területhez kapcsolódik, míg utóbbiaknak leginkább a hírneve származik abból, hogy előállításuk legalább egy meghatározó része egy bizonyos helyszínhez kötődik.

Ugyan a nemzetközi kereskedelmi megállapodások létrejöttét a földrajzi árujelzők csak kismértékben befolyásolják (JÁMBOR és TÖRÖK, 2019), az Európai Unió számára a földrajzi árujelzők kérdése központi szerepet játszik - nem csak az uniós élelemiszerminőség-politikában, hanem a nemzetközi kereskedelmében is (ENGELHARDT, 2015). A 2019 végén megalakuló von der Leyen bizottság is fó prioritásként kezeli, hiszen ezeket a termékeket a kiemelkedő minőségű élelmiszerek letéteményesének tartja, melyek „biztosítják, hogy az európai kulturális, gasztronómiai és helyi örökség megőrzésre kerül és bizonyítottan autentikus termékekként jelennek meg szerte a világon" (VON DER LEYEN, 2019:5).

Annak ellenére, hogy az Európai Bizottság számos fórumon hangoztatja a földrajzi árujelzők fontosságát, a szakterülethez kapcsolódó és rendelkezésre bocsátott adatok mennyisége és minősége meglehetősen szűkös (részletesebben lásd: TÖRÖK és MOIR (2018b)) és ez a földrajzi árujelzők gazdasági és társadalmi jelentőségének megértése során komoly problémát jelent (LONDON ECONOMICS, 2008). Az európai földrajzi árujelzős termékek regiszteréből (DOOR) mindösszesen néhány technikai információt tudhatunk meg, s csupán a legna- gyobb, földrajzi árujelzős termékeket előállító országoknál (pl. Olaszország és Franciaország) érhetünk el egyéb forrásból átfogó piaci adatokat.

A magyar szakpolitika 2015-ben meghirdette a Földrajzi Árujelzők Programját, melynek célja, hogy jelentősen nőjön az EU által elismert földrajzi árujelzős magyar élelmiszerek száma, továbbá hogy a már oltalomban részesülő termékek számára a földrajzi árujelzők által kínált lehetőségeket jobban kiaknázza (AGRÁRMINISZTÉRIUM, 2019). 2015-ig összesen 13 Magyarországról származó mezőgazdasági termék és élelmiszer szerepelt az EU hivatalos regiszterében, míg azóta további egy terméket jegyeztek be, illetve folyamatban van újabb 14 termék bejegyzése is (EURÓPAI BIZOTTSÁG, 2019), köszönhetően a kormányzati programnak.

Mindezek alapján jelen kutatásunkban arra vállalkozunk, hogy a diszkontok példáján keresztül a Magyarországon elérhető földrajzi árujelzőkkel ellátott élelmiszerek (a borokat és párlatokat nem beleértve) piacméretét, illetve a közvetlen helyettesítő termékeikhez képest mért árprémiumát megbecsüljük, s empirikus adatokkal hozzájáruljunk a téma ilyen szempontból meglehetősen hiányos szakirodalmához.

\subsection{A földrajzi árujelzős termékek piac- mérete - Market Size of Products with Geographical Indication (GI)}

A földrajzi árujelzős élelmiszerek valós piaci részesedéséről csak korlátozottan találhatunk adatokat az eddig megjelent tanulmányokban. Az EU hivatalos adatbázisa (DOOR) nem szolgáltat ilyen jellegü információkat, de azt megállapíthatjuk, hogy a legtöbb földrajzi árujelzős termék a mediterrán EU tagországokból származik (csökkenő sorrendben: Olaszország, Franciaország, Spanyolország, Portugália és Görögország), s a legtöbb ilyen termék zöldség vagy gyümölcs, sajt, feldolgozott és nyers hús, illetve olaj (TÖRÖK és MOIR, 2018a).

Az Európai Bizottság számára több tanulmány is készült a földrajzi árujelzős termékek helyzetéről. Például a LONDON ECONOMICS (2008) tanulmányából kiderül, hogy a földrajzi árujelzőkkel rendelkező termékek előál- 
lítóinak és feldolgozóinak számát tekintve (is) Olaszország volt a leginkább érdekelt, mivel itt a gazdálkodók 3,4\%-a, a feldolgozóknak pedig 17,7\%-a érintett volt. Franciaországban a mezőgazdasági termelők 14,7\%-a állított elő OEM, és 2,9\%-a OFJ élelmiszert. Az árbevételt tekintve Franciaországban, Németországban, Olaszországban és Spanyolországban az OEM/OFJ termékek az összes élelmiszeripari termék forgalmának 1-5\%-át (kb. 10 milliárd euró) tették ki 2008-ban. Az AND-International (2012) jelentéséből megtudhatjuk, hogy a földrajzi árujelzős termékek az európai élelmiszer- és italértékesítés 5,7\%-át tették ki 2010ben. A földrajzi árujelzős termelés részesedése a teljes élelmiszertermeléshez viszonyítva csak Franciaországban (14,5\%) haladta meg a 10\%ot. Olaszországban, Görögországban és Portugáliában ez az arány 8-10\% között mozgott, viszont 15 tagállam esetén még a 4\%-ot sem haladta meg ez az érték. 2010-ben az összes földrajzi árujelzős termelés 19,5\%-át exportálták az EU-n kívüli piacokra, míg 20,4\%-át értékesítették az Európai Unión belül, de az előállító országon kívül, ezeknek a termékeknek a legfontosabb felvevőpiaca tehát mindenhol a termelési ország saját hazai vásárlói.

Az egyes országok piacait vizsgáló tanulmányok nagyfokú koncentrációt mutattak ki: Olaszországban a közel 300 földrajzi árujelzős termékből mindösszesen 15 termék (elsősorban sajtok és húskészítmények) adta ki a teljes termelés 90\%-át (ARFINI és CAPELLI, 2009).

TIBÉRIO és FRANCISCO (2012) 2007-ben a portugál földrajzi árujelzős termékek piacát mintegy 70 millió euró nagyságúra becsülte, ugyanakkor felhívta a figyelmet arra, hogy ezeknek a termékeknek csak a 68\%-a került piaci forgalomba, a többi saját felhasználás, illetve barterügyletek tárgyát képezte. Az olasz sajtpiacot vizsgálva nagy különbségeket állapítottak meg GALLI és munkatársai (2011): egyes nagy piacmérettel rendelkező sajtok jelentős külföldi értékesítést generáltak, azonban a legtöbb, kisebb termelési volumennel bíró termék esetében leginkább a belföldi, azon belül is a helyi piacok domináltak. A nemzetközi kereskedelmet vizsgálva LEUFKENS (2017) azt találta, hogy elsősorban az OFJ termékek esetében van a földrajzi árujelzőknek pozitív hatása az exportra. Hasonló megállapításra ju- tottak BELLETTI és munkatársai (2009) toszkán olívaolajok esetében: az Európán kívüli piacokra elsősorban az OFJ, míg az olasz, illetve EU-s piacokra pedig inkább az OEM termékek kerültek.

A fentiek alapján megállapítható, hogy a földrajzi árujelzős termékek csak egyes európai országokban meghatározóak, azonban arányuk ott sem jelentős. A termékek nagy részét belföldön értékesítik, míg exportra leginkább az OFJ termékek esetében kerül sor.

\subsection{A földrajzi árujelzós termékek ár- prémiuma - The Price Premium of GI Products}

A földrajzi árujelzővel rendelkező élelmiszerek piacméretén kívül kutatásunkban az árprémiummal foglalkozunk. Ezzel a témával kapcsolatban is készültek korábban különböző vizsgálatok. Módszertanukat tekintve leggyakrabban kérdőívekkel és interjúkkal próbálták kideríteni, hogy a fogyasztók hajlandóak-e többet fizetni az OEM/OFJ címkével ellátott termékekért. Ezen kutatások eredményei azt mutatják, hogy a legtöbb esetben a válaszadók hajlandóak voltak felárat fizetni az OEM vagy OFJ termékekért (többek között APRILE és GALLINA, 2008; BRYŁA, 2017; FOTOPOULOS et al., 2011; GROOT és ALBISU, 2009; SAHELICES et al., 2017; URBANO et al., 2008). Született ugyanakkor ezzel ellentétes eredmény is: BONNET és SIMIONI (2001) Franciaországban sajtokon végzett kutatásukban arra jutottak paneladatok alapján, hogy a fogyasztók nem hajlandóak többet kifizetni az OEM termékekért.

APRILE és munkatársai (2012) kísérleti kiválasztást és véletlenszerű logit modellt használva az olívaolajok piacán arra jutottak, hogy a vizsgált jelölések közül, a fogyasztók az OEM címkéért hajlandók a legnagyobb árprémiumot kifizetni, ezt követi a bio jelölés, majd az „extra-szűz" megnevezéssel ellátott olívaolaj és végül az OFJ címke. MENAPACE és munkatársai (2008) is az olívaolajat vizsgálták kanadai fogyasztók körében, ahol diszkrét választási modell és multinominális vegyes logit modell alkalmazásával arra az eredményre jutottak, hogy a válaszadók mind az országeredet, mind a földrajzi árujelzős címkéket fontosnak tartják, de a kanadai vásárlók többre értékelik az 
országeredet-megjelölést, mint a földrajzi árujelzőket. VECCHIO és ANNUNZIATA (2011) kísérleti választást alkalmazott olasz kutatásában, hogy feltárják a sonka és a sajt iparágban a földrajzi árujelzők ismeretét és a felárfizetési hajlandóságot. Annak ellenére, hogy a megkérdezett fogyasztók hiányos ismeretekkel rendelkeztek az OEM és az OFJ címkékről, az eredményeik rámutattak arra, hogy a válaszadók közel 58\%-a hajlandó megfizetni a 20\%-ot meghaladó prémiumárat ezekért a termékekért és a fogyasztók további 27\%-a 10\%-os többletárat még hajlandó kifizetni. Azok közül, akik az OEM címkét kiválóan ismerték, 37,5\% hajlandó legfeljebb 40\%-os prémium árat fizetni, míg azok közül, akik számára ismeretlenek voltak ezek a címkék, 34,5\% azt válaszolta, hogy maximum 10\%-os árprémiumot hajlandó kifizetni ezekért a termékekért.

A fogyasztói oldal vizsgálata alapján az állapítható meg, hogy a vásárlók jellemzően hajlandóak többet fizetni a földrajzi árujelzős termékekért, ugyanakkor az árprémium nagysága jelentős eltéréseket mutathat.

\section{ANYAg ÉS MÓDSZER - MATERIAL} AND METHOD

Annak érdekében, hogy valós piaci adatokkal rendelkezzünk, havonta próbavásárlást végeztünk egy éven keresztül (2018. január-december) a három Magyarországon múködő élelmiszerdiszkont (Lidl, Aldi, és Penny Market) egy-egy budapesti üzletében. Próbavásárlást gyakran alkalmaznak különböző kutatási területeken (például LIU és munkatársai (2014) éttermeket értékelt, vagy YAOYUNEYONG és munkatársai (2018) hotelek vizsgálatához), hiszen ezzel a módszerrel a kutató a fogyasztó szemszögéből láthatja a termékeket, szolgáltatásokat.

Ahhoz, hogy összehasonlítható eredményeket kapjunk, minden hónapban ugyanazon a napon látogattuk meg az adott lánc ugyanazon üzletét (a hónap minden harmadik csütörtökén, mivel minden láncban csütörtökön kezdődik egy-egy promóciós időszak). Elsőként összegyưjtöttük az adott bolt kínálatában elérhető összes földrajzi árujelzővel ellátott termékét és azok legközelebbi helyettesítőit (pl. Feta OEM sajt esetében egy nem földrajzi árujelzős krémfehér sajt). Ezután figyelemmel kísértük a legfontosabb adataikat: az elérhetőségüket, illetve különös figyelmet fordítottunk az árak alakulására. Ezután az így kapott idősoros adatokat utólag elemeztük. A bemutatott módszerrel egy összesen 816 megfigyelésből álló adatbázist sikerült létrehoznunk a további vizsgálatok és elemzések elvégzéséhez.

Jelen tanulmányunkban tehát az élelmiszerdiszkontokban megfigyelhető kiskereskedelmi árakat és elérhetőséget vizsgáljuk, s a diszkontok következő fejezetben bemutatott jellemzői alapján azt várjuk, hogy az itt kapott eredmények mind az árprémium (a magyar élelmiszerdiszkontok továbbra is elsősorban az árérzékeny fogyasztókat célozzák meg), mind pedig a piacméret (a diszkontok kínálata a leginkább limitált) tekintetében alulról tudja becsülni a magyar piac jellemzőit. A szakirodalom és az előzetes várakozások alapján arra számítunk, hogy a magyarországi kínálat meglehetősen szúkös, ahol jellemzően a nagy dél-európai termelő országok (Olaszország, Franciaország és Spanyolország) magas feldolgozottsági szintű (sajt- és húskészítmények) OFJ termékei a legjobban elérhetőek, kiegészülve magyar, illetve német termékekkel (ez utóbbit az indokolja, hogy mindhárom vizsgált élelmiszerlánc német tulajdonban van).

\section{EREDMÉNYEK - RESUltS}

\subsection{Miért a diszkontok? - Why the Discounters?}

Vizsgálatunkat a Magyarországon található diszkont áruházakban végeztük. Ennek elsődleges oka az volt, hogy ezek az üzletek látványosan terjeszkedtek az elmúlt években, Magyarországon és Európa-szerte egyaránt, ezzel az átlagfogyasztók számára szinte mindenhol elérhetővé váltak. HÖKELEKLI és munkatársai (2017) tanulmánya szerint 2014-ben az Egyesült Királyság vásárlóinak több mint fele (51\%) havonta látogatott el diszkont áruházba, és az ezt megelőző két évben több mint kétszeresére, azaz 5\%-ról 12\%-ra nőtt azoknak a fogyasztóknak a száma, akik heti „fó bevásárlásukat” diszkontokban végezték. Az Aldi és a Lidl 2016- 
ban 28 európai országban múködött, ahol átlagosan 10\%-os részesedést értek el, de például Németországban és Ausztriában ez a szám akár a 35\%-ot is meghaladta, és ez azóta is növekvő tendenciát mutat (GIJSBRECHTS et al., 2018). Belgiumban 2013. évi felmérések azt mutatták, hogy a diszkontok az élelmiszer-kiskereskedelmi szolgáltatások 42,6\%-át tették ki az országban (WILLEMS et al., 2016).

Egy másik látványos változást jelentett az elmúlt években az, hogy a diszkont áruházak újrapozícionálták magukat, már nem feltétlenül csak a legolcsóbb áruházként akartak megjelenni a piacon. A kezdeti sikerüket az biztosította, hogy nem követték a termékválaszték diverzifikálásának tendenciáját, hanem továbbra is a korlátozott választékra koncentráltak a napi fogyasztási cikkek piacán, mivel ezeket nagy mennyiségben lehet megvásárolni és alacsony áron értékesíteni. Az Aldi, Lidl és hasonló diszkontok gyors növekedését Németországban ebben az időszakban az is elősegítette, hogy az ország kiskereskedelmet érintő politikája védelmet nyújtott a független közepes méretű kiskereskedőknek azzal, hogy méretkorlátozást vezetett be a városközpontokon és speciális övezeteken kívüli üzletekre. 1986 óta az élelmiszerboltok a legtöbb helyen körülbelül $800 \mathrm{~m}^{2}$ nagyságú értékesítési területre korlátozódtak (GEPPERT et al., 2015). Az elmúlt években viszont a diszkontok újrapozícionálták magukat és megfigyelhető az a tendencia, hogy már friss árufélék, bio-élelmiszerek, minőségi borok és jó minőségü saját márkás termékek is széles választékban megtalálhatóak az üzleteikben (ŚMIGIELSKA és STEFAŃSKA, 2017).

A diszkontok kínálatában kevesebb termék jelenik meg, (kb. 1300-1 400 áru) mint a szupermarketekben (30 ooo áru) (HÖKELEKLI et al., 2017), viszont a diszkont áruházak kínálata állandó, ritkábban változik az összetétele, mint más típusú boltoknál. Fontos tulajdonsága továbbá a diszkontoknak, hogy a kínálatuk jelentős részét képezik a saját márkás termékek (NEUMEIER, 2015; WILLEMS et al., 2016). A diszkontok jobban befolyásolhatják saját márkájukkal a termékek kiskereskedelmi árait, ami hozzájárul a diszkontok eltérő árazási stratégiájához (LIU et al., 2019). Azért kedveli a kereskedelem a sajátmárkás termékeket, mert általában nagyobb bruttó árrés realizálható ezeken a termékeken, illetve segíthetik a megkülönböztetést a versenytársakkal szemben, hiszen a többi áruházban ezek a márkák nem kaphatóak (LARSON, 2018). A saját márkák elterjedése erőteljesen növekszik, piaci részesedésük körülbelül $30 \%$ volt 2014-ben (MONIER-DILHAN, 2018). LARSON (2018) tanulmányában meghatározza, hogy a potenciálisan sajátmárkás termékeket kereső fogyasztók leginkább egyetemi végzettségű és hedonista vásárlók, továbbá a kiskereskedőknek a férfiakat és a magasabb jövedelmű háztartásokat érdemes megcélozni ezekkel a termékekkel.

Ami a magyarországi élelmiszer-kiskereskedelmet illeti, a boltok száma alapján megállapítható, hogy leginkább a COOP, a CBA és a Reál dominálnak, s a diszkontok közül a Penny Market rendelkezik a legtöbb kereskedelmi egységgel, a 218 üzletével az ötödik legnagyobb Magyarországon. A három diszkont összesen 534 bolttal rendelkezett 2018 végén. Ugyanakkor, ha azt nézzük, hogy a boltok száma az elmúlt 10 évben milyen ütemben növekedett, akkor azt láthatjuk, hogy mindhárom diszkont a legdinamikusabban terjeszkedő láncok között van. Az Aldi üzleteinek száma éves szinten átlagosan több mint 10\%-kal bővült, míg a Lidl átlagosan 4,3\%-kal, a Penny Market pedig 2,3\%-kal növelte boltjainak számát (1. ábra).

A forgalmat vizsgálva láthatjuk, hogy ugyan abszolút értékben a Tesco, a Coop és a Spar bonyolította a legnagyobb forgalmat 2018-ban, azonban ami az éves forgalomnövekedéseket illeti Magyarországon, az elmúlt 10 évben a diszkontok könyvelhették el a legnagyobb bővülést. Az Aldi növekedett a legdinamikusabban, a Lidl második ebben a rangsorban, de a Penny Market is több mint 5\%-os növekedést produkált a 2009 és 2018 közötti időszakban (2. ábra).

Ezekből az adatokból láthatjuk, hogy a diszkontok Magyarországon is követik az európai trendeket, folyamatosan növekednek és egyre nagyobb részt hódítanak meg a kiskereskedelmi szektorban. 


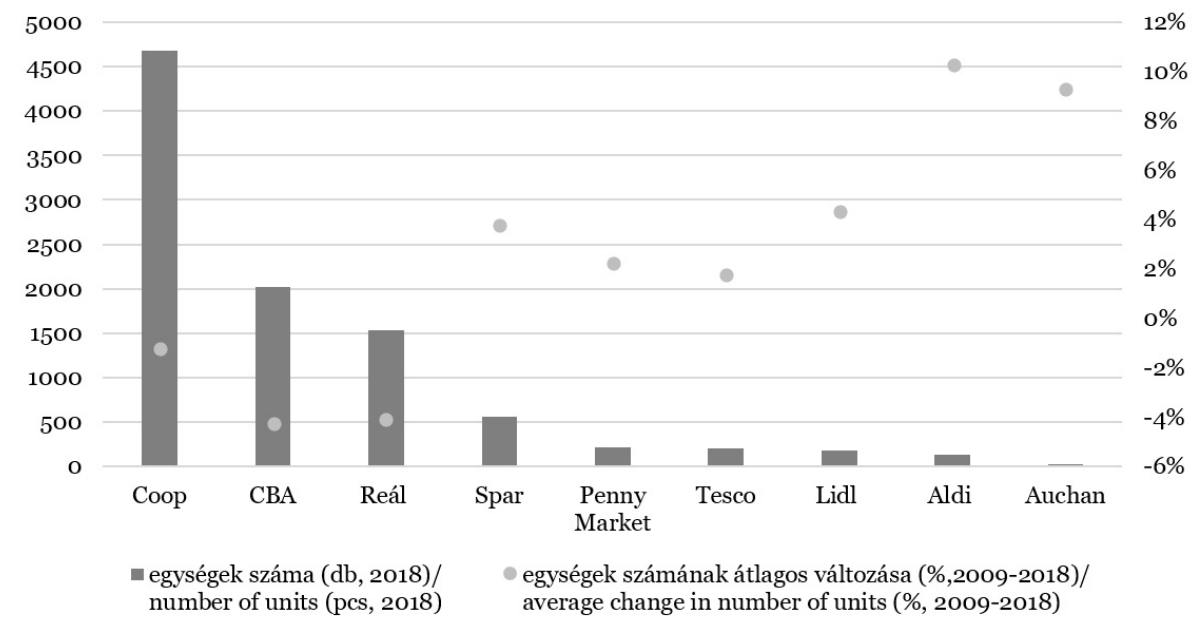

\section{1. ÁBRA} number of units (pcs, 2018)

Élelmiszer-kiskereskedelmi egységek száma Magyarországon 2018-ban és egységek változása 2009-2018 között (\%)

(Number of Food Retail Units in Hungary in 2018 and Change in Units Between 2009 and $2018(\%))$

Forrás (Source): Saját szerkesztés a TRADE MAGAZIN (2019) alapján (Authors' own edit based on the TRADE MAGAZINE (2019))

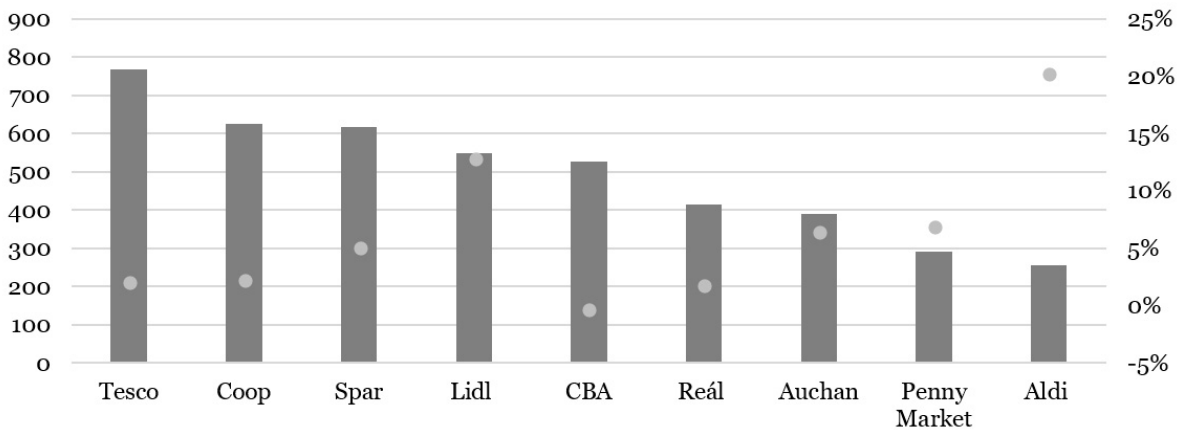
—éves forgalom 2018-ban (milliárd Ft)/ éves forgalom átlagos változása (\%, 2009-2018)/
annual turnover in 2018 (HUF billion)

2. ÁBRA

Élelmiszer kiskereskedelmi láncok éves forgalma Magyarországon 2018-ban (milliárd Ft) és éves forgalom átlagos változása 2009-2018 között (\%)

(Annual Turnover of Food Retail Chains in Hungary in 2018 (HUF Billion) and Average Change in Annual Turnover Between 2009 and 2018 (\%))

Forrás (Source): Saját szerkesztés a TRADE MAGAZIN (2019) alapján (Authors' own edit based on the TRADE MAGAZINE (2019)) 
A 3. ábra alapján egyértelmüen kirajzolódik, hogy ugyan a boltok számát tekintve 2018-ban csupán a magyar piac 6\%-át fedték le a dinamikusan növekvő diszkont áruházak, de ha a forgalmat vizsgáljuk, akkor a teljes piac több mint negyedét magáénak tudhatta ez a szegmens.
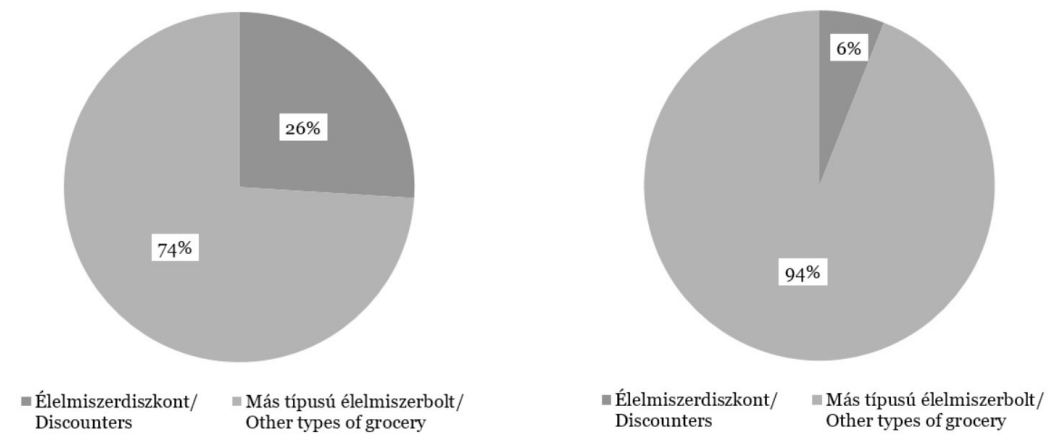

3. ÁBRA

Élelmiszerd

Other types of grocery

FIG. 3

Forgalom (bal oldali ábra) és boltok száma (jobb oldali ábra) az élelmiszer-kiskereskedelemben 2018-ban

(Turnover (Figure ont he left) and Number of Stores (Figure ont he right) in Food Retail in 2018)

Forrás (Source): Saját szerkesztés a TRADE MAGAZIN (2019) alapján (Authors'own edit based on the TRADE MAGAZINE (2019))

A fenti adatokból láthatjuk, hogy a magyar diszkontok vizsgálatával kiváló képet kaphatunk a jelenlegi magyar élelmiszer-kiskereskedelemben zajló folyamatokról. Ezek a láncok Magyarországon és Európában is többnyire elérhetőek az átlagos fogyasztók számára, boltjaik számának és forgalmuk növekedéséből arra következtethetünk, hogy egyre több vásárló tér be ezekbe az üzletekbe, tehát a jövőben várhatóan még nagyobb szerepük lesz a kiskereskedelemben. A választásunkat továbbá az is indokolja, hogy egy közelmúltban végzett fogyasztói felmérés (TÖRÖK, 2019) eredményei szerint a földrajzi árujelzős termékek „előiskolájaként” tekintett HÍR védjegyes termékek iránt leginkább azok a fogyasztók a nyitottak, akik élelmiszer-beszerzéseiket elsősorban diszkontokban végzik, és ezek a fogyasztók nagy valószínüséggel rendszeres vásárlásóivá is válnak ezeknek a termékeknek.

\subsection{Piacméret - Market Size}

A próbavásárlásokon alapuló megfigyeléseink számos egyértelmű eredményt mutatnak. Először is, a magyar diszkontokban elérhető földrajzi árujelzős termékek száma korlátozott, az alap élelmiszerkínálatban 8-16-féle földrajzi árujelzős termék érhető el (4. ábra). Másrészt a kínálat meglehetősen állandó, az ilyen jelzéssel ellátott termékek ugyan korlátozott számban, de mindig elérhetőek a fogyasztók számára, és a láncok alaptermék-portfóliójába tartoznak. A földrajzi árujelzővel ellátott termékek száma csak a tematikus promóciók során emelkedett jelentősen, például az Aldi és a Lidl áruházláncok mindegyikében évente akár többször is megtartott „olasz héten”. Harmadrészt fontos kiemelni, hogy a sajátmárkás termékek száma a földrajzi árujelzős termékek esetében is meghatározó, hiszen a Lidl és a Penny Market esetében ezeknek az aránya 80-90\%, míg egyedül az Aldinál volt csak 50\%. 


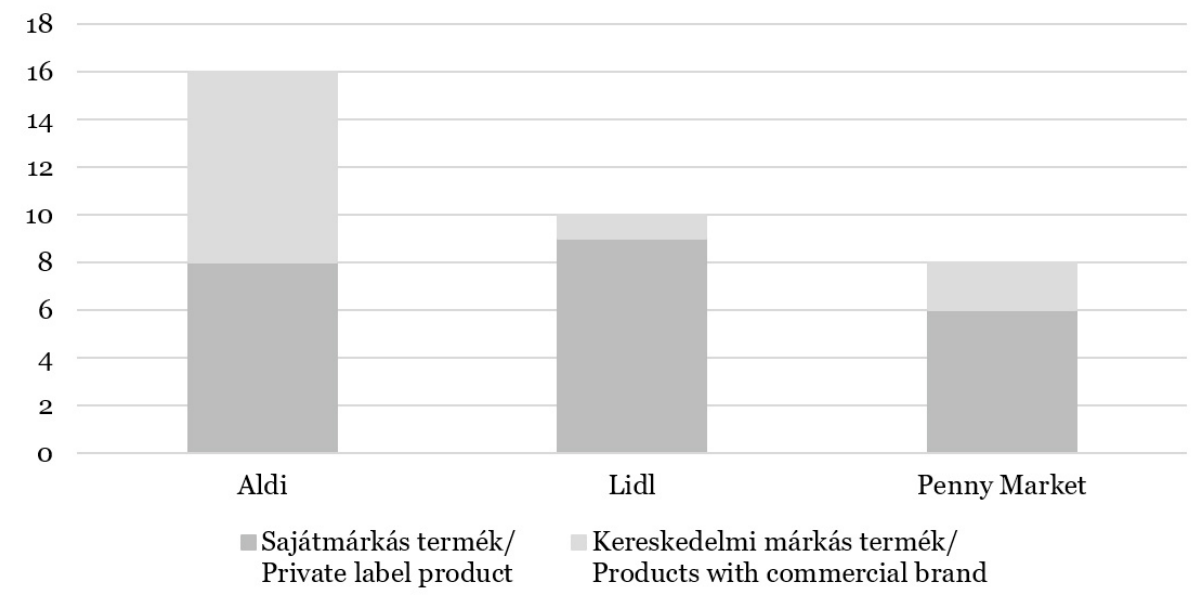

4. ÁBRA

Élelmiszerdiszkontokban elérhető földrajzi árujelzős termékek száma (db) (Number of GI Products Available in Food Discount Stores (pcs))

Forrás (Source): Saját szerkesztés (Authors'own compilation)

A DOOR adatbázishoz viszonyítva, a vizsgált áruházakban az OEM termékek nagyobb arányban szerepeltek, mint az OFJ termékek, szemben a DOOR adatbázissal, ahol ez éppen elenkező megoszlást mutat (5. ábra).
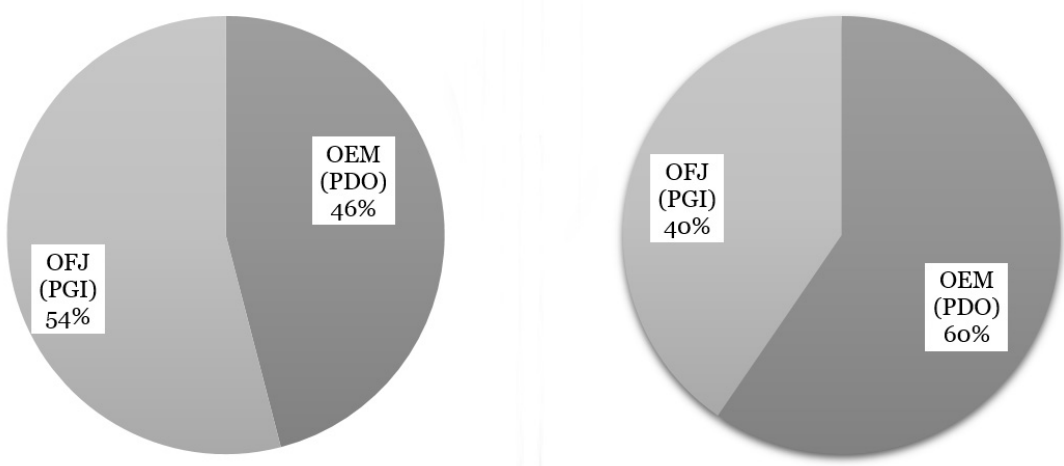

5. ÁBRA

FIG. 5

Az OEM és az OFJ termékek megoszlása a DOOR adatbázisban (bal oldali ábra) és a hazai diszkontokban (jobb oldali ábra)

(Distribution of PDO and PGI Products in the DOOR Database (Figure on the left) and in Hungarian Discounters (Figure on the right))

Forrás (Source): Saját szerkesztés (Authors'own compilation)

Ezután tovább vizsgáltuk, hogy a DOOR adatbázishoz viszonyítva a hazai diszkont áruházakban milyen a származási országok és az élelmiszerkategóriák közötti megoszlás. Az 1. táblázatból jól látszik, hogy a legtöbb elérhető termék (82\%) importból származik, továbbá a DOOR adatbázisban, és az általunk vizsgált diszkontokban is az olasz termékek voltak a legnagyobb számban megtalálhatóak. Ugyanakkor amíg a DOOR adatbázisban a francia, spanyol és portugál termékek is nagy számmal jelen vannak, addig a magyarországi Penny, Lidl 
és Aldi polcain ezekkel a termékekkel egyáltalán nem lehetett találkozni. Viszonylag nagy részesedése volt még hazánkban a görög és német termékeknek is, és nem meglepően a magyar termékek is jóval nagyobb arányban (18\%ban) szerepeltek a kínálatban, mint ahogyan az a DOOR adatbázis alapján indokolt lenne.

Ha a termékkategóriák alapján elemezzük a kínálatot, akkor láthatjuk, hogy míg a DOOR adatbázisban a zöldség és gyümölcs kategória tartalmazza a legtöbb terméket, addig a hazai diszkontokban a sajtok (50\%) és a feldolgozott húsok (29\%) domináltak leginkább (2. táblázat).

Földrajzi árujelzőkkel ellátott élelmiszerek származási hely szerinti össszehasonlítás a DOOR adatbázis és a magyar diszkontáruházak között, \% (Comparison of GI Foods by Origin Between DOOR Database and Hungarian Discount Stores, \%)

\begin{tabular}{lccc}
\hline \multicolumn{1}{c}{ Ország (Country) } & DOOR & $\begin{array}{c}\text { Magyar } \\
\text { diszkontáruházak } \\
\text { (Hungarian discount } \\
\text { stores) }\end{array}$ & Különbség (Difference) \\
\hline Olaszország (Italy) & 21 & 41 & 20 \\
\hline Franciaország (France) & 18 & 0 & -18 \\
\hline Spanyolország (Spain) & 14 & 0 & -14 \\
\hline Portugália (Portugal) & 10 & 0 & -10 \\
\hline Görögország (Greece) & 8 & 18 & 10 \\
\hline Németország (Germany) & 7 & 15 & 8 \\
\hline Magyarország (Hungary) & 1 & 18 & 17 \\
\hline Egyéb (Other) & 21 & 8 & -13 \\
\hline
\end{tabular}

Forrás (Source): Saját szerkesztés (Authors' own compilation)

2. TÁBLÁZAT

TABLE 2

Földrajzi árujelzőkkel ellátott élelmiszerek kategória szerinti össszehasonlítás a DOOR adat-

bázis és a magyar diszkontáruházak között, \%

(Comparison of GI Foods by Category Between DOOR Database and Hungarian Discount Stores, \%)

\begin{tabular}{lccc}
\hline Kategória (Category) & DOOR & $\begin{array}{c}\text { Magyar } \\
\text { diszkontáruházak } \\
\text { (Hungarian discount } \\
\text { stores) }\end{array}$ & Különbség (Difference) \\
\hline $\begin{array}{l}\text { Zöldség, gyümölcs } \\
\text { (Vegetables, fruit) }\end{array}$ & 28 & 3 & -25 \\
\hline Sajtok (Cheese) & 17 & 50 & 33 \\
\hline $\begin{array}{l}\text { Feldolgozott húsok } \\
\text { (Processed meat) }\end{array}$ & 13 & 29 & 16 \\
\hline Friss húsok (Fresh meat) & 12 & 0 & -12 \\
\hline Olajok (Oils) & 10 & 9 & -1 \\
\hline Péksütemények (Pastries) & 6 & 0 & 4 \\
\hline Fúszerek (Spices) & 5 & 9 & -10 \\
\hline Egyéb (Other) & 10 & 0 & -6 \\
\hline
\end{tabular}

Forrás (Source): Saját szerkesztés (Authors'own compilation) 


\section{3•3. Árprémium - Price Premium}

A földrajzi árujelzővel ellátott termékek átlagos árprémiumát tekintve az egyes diszkontok között is jelentős különbség figyelhető meg ( 6 . ábra): míg az Aldiban 29\% volt ez az érték, a Penny Marketben 46\%, a legmagasabb pedig a Lidlben 54\%. Összességében az átlagos felár mintegy $43 \%$ körül mozgott, azonban fontos kiemelni, hogy a kalkulációhoz csak azokat a termékeket használtuk fel, amelyeknek közvetlen helyettesítő terméke is elérhető volt az adott kínálatban. Ki kell emelni, hogy az árak nem igazán változtak a különböző időpontban végzett megfigyelések során, csupán egy-egy alkalommal szerepeltek ezek a termékek alacsonyabb árral az akciós kínálatban. Az árprémium számításában a 12 hónapban legjellemzőbb árakat használtuk mind a földrajzi árujelzős termékek, mind pedig a helyettesítő termékek esetében. Ugyan az árak nem változtak, de a kínálatban volt némi eltérés, azonban nem zártuk ki a vizsgálatból azokat a termékeket, melyek egy-egy hónapban nem voltak elérhetőek. Azon egyedi tulajdonságokkal bíró földrajzi árujelzős termékek (pl. Gorgonzola sajt), amelyeknek nem volt közvetlen alternatívája, nem képezték a számításaink alapját.

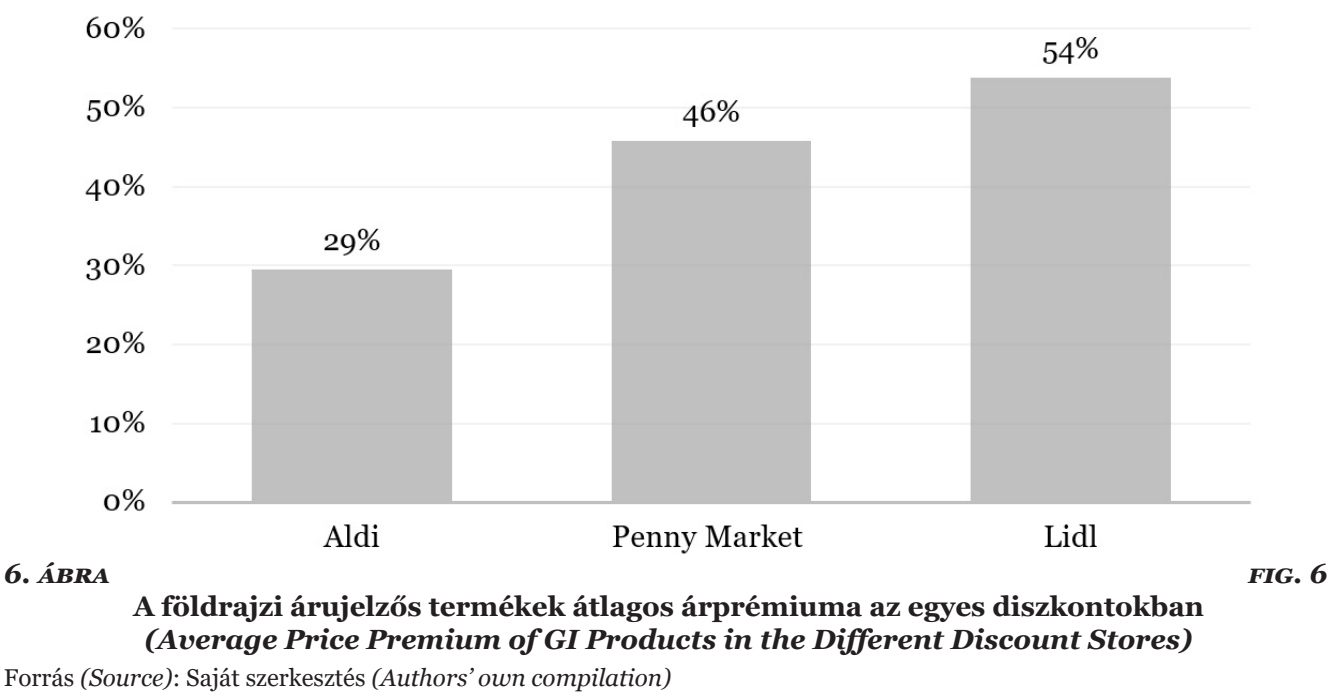

Ha az OEM és OFJ termékeket külön vizsgáljuk az egyes diszkontáruházakban (7. ábra), azt láthatjuk, hogy az Aldiban nincs nagy különbség a földrajzi árujelzős termékek átlagos árprémiuma között. A Lidlben nagyobb árprémiummal (69\%) rendelkeznek az OEM kategóriába sorolt termékek, míg a Penny Marketben az OFJ termékek átlagos árprémiuma volt magasabb (62\%).

Származási országot tekintve az átlagos árprémium a görög és osztrák élelmiszereknél volt a legnagyobb (55\%), de csak néhány százalékponttal maradnak le a német és magyar termékek (3. táblázat).

A termékkategóriákat tekintve (4. táblázat) a füszerek realizálták a legmagasabb felárat, míg a zöldség-gyümölcs kategória 55\%-os átlagos árprémiummal a második legmagasabb. A további elérhető termékcsoportok nagyságrendileg hasonló (33-37\%) átlagos árprémiummal rendelkeztek. 
$80 \%$

$70 \%$

$69 \%$

$60 \%$

$50 \%$

$40 \%$

$30 \%$

$20 \%$

$10 \%$

$0 \%$
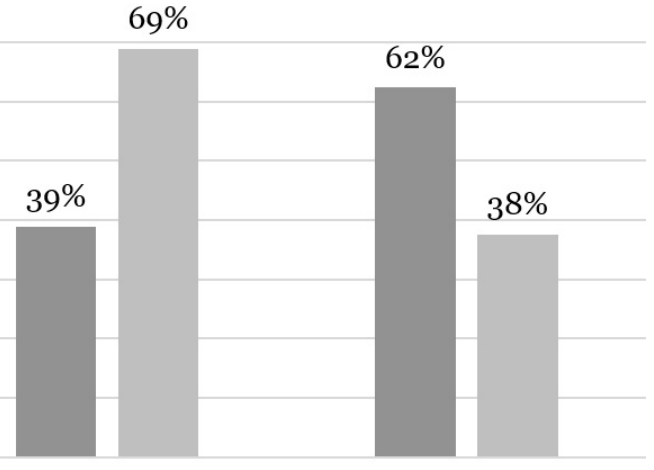

Aldi

Lidl

Penny

- OFJ (PGI) $\square$ OEM (PDO)

7. ÁBRA

Az OEM és OFJ termékek átlagos árprémiuma

FIG. 7

(Average Price Premium of PDO and PGI Products)

Forrás (Source): Saját szerkesztés (Authors'own compilation)

3. TÁBLÁZAT

Földrajzi árujelzőkkel ellátott élelmiszerek származási hely szerinti

TABLE 3 prémiumárának össszehasonlítása, \%

(Comparison of Premium Price of GI Food Products by Origin,\%)

\begin{tabular}{ll}
\hline \multicolumn{1}{c}{ Ország (Country) } & Átlagos árprémium (Average price premium) \\
\hline Olaszország (Italy) & 19 \\
\hline Franciaország (France) & - \\
\hline Spanyolország (Spain) & - \\
\hline Portugália (Portugal) & 55 \\
\hline Görögország (Greece) & 47 \\
\hline Németország (Germany) & 45 \\
\hline Magyarország (Hungary) & 55 \\
\hline Egyéb (Other) & 55 \\
\hline
\end{tabular}

Forrás (Source): Saját szerkesztés (Authors'own compilation)

4. TÁBLÁZAT

Földrajzi árujelzőkkel ellátott élelmiszerek kategória szerinti

TABLE 4 prémiumárának össszehasonlítása, \% (Comparison of Premium Prices by Category of GI food,\%)

\begin{tabular}{lc}
\hline \multicolumn{1}{c}{ Termékkategória (Product category) } & Átlagos árprémium (Average price premium) \\
\hline Zöldség, gyümölcs (Vegetables, fruit) & 55 \\
\hline Sajtok (Cheese) & 33 \\
\hline Feldolgozat húsok (Processed meat) & 37 \\
\hline Olajok (Oils) & 33 \\
\hline Fúszerek (Spices) & 111 \\
\hline
\end{tabular}

Forrás (Source): Saját szerkesztés (Authors'own compilation) 


\section{KöVETKEZTETÉSEK ÉS}

\section{JAVASLATOK - CONCLUSIONS AND RECOMMENDATIONS}

A szakirodalomból és az elmúlt egy évtized piaci folyamataiból is jól kitűnik, hogy mind Európa-szerte, mind pedig Magyarországon a diszkontok térnyerése az élelmiszer-kiskereskedelemben megkérdőjelezhetetlen. Az elmúlt években ezek a típusú boltok realizálták a legnagyobb ütemú boltszám- és forgalomnövekedést, éppen ezért az itt megfigyelhető tendenciákkal jól jellemezhetjük a magyar élelmiszer-kiskereskedelem folyamatait, még ha a diszkontokon végzett vizsgálatok nem is tekinthetőek az egész ágazatra nézve reprezentatívnak.

Eredményeink azt mutatják, hogy a földrajzi árujelzőkkel ellátott élelmiszereknek jelenleg korlátozott jelentőségük van a magyar élelmiszerpiacon, mind a termékek számát, mind pedig azok részarányát tekintve. Az ilyen típusú termékek csak kis számban kerülnek be az élelmiszerdiszkontok kínálatába, az egyes diszkontokban a földrajzi árujelzős termékek száma nem érte el az áruházak teljes állandó kínálatának 1\%-át sem (a termékek darabszámát tekintve). Ugyanakkor annak a ténye, hogy a szúkös kínálatuk állandó, továbbá hogy a diszkontokban elérhető földrajzi árujelzős termékek döntő hányada sajátmárkás termék, mind azt jelzik, hogy azok a termékek, melyek bekerülnek a kínálatba, stabilan ott szerepelnek. Ez lehetőséget jelent azoknak a jelenlegi, illetve majdani magyar földrajzi árujelzős termékeknek is, amelyek tudják vállalni a diszkontok által megkövetelt beszállítási feltételeket.

Amennyiben a DOOR adatbázist tekintjük viszonyítási alapnak, úgy elmondható, hogy a magyarországi élelmiszerdiszkontokban az OEM termékek aránya sokkal magasabb. Ez annak fényében is meglepő, hogy a szakirodalom alapján az OFJ termékek nemzetközi kereskedelme a gyakoribb. A jelenségre magyarázatként az szolgálhat, hogy a szűkös kínálat legnagyobb részét pontosan azok az OEM termékek teszik ki, melyeknek a nemzetközi kereskedelme kifejezetten meghatározónak tekinthető (pl. olasz és görög sajtok). A termékek származási helye alapján megállapíthatjuk, hogy a legtöbb élelmiszer importból származik, ugyanakkor a magyar termékek 18\%-os aránya jelentősen meghaladja a magyar termékek DOOR adatbázisban szereplő részesedését. A helyi beszerzést egyre fontosabb szempontként kezelő diszkontok esetében tehát a hazai földrajzi árujelzős termékeknek is van létjogosultsága. A hazai termékeken túl az olasz, görög és német termékek felülreprezentáltak. Az olasz termékek 41\%-os részesedése ugyanakkor nem nevezhető meglepőnek, tekintve hogy Olaszország a legmeghatározóbb földrajzi árujelzős élelmiszereket előállító ország világviszonylatban is, míg a német termékek magas arányát az magyarázhatja, hogy a vizsgált diszkontok mind német tulajdonban vannak, amely hatással lehet a beszerzési politikájukra is. A többi mediterrán ország (Franciaország, Spanyolország és Portugália) termékeinek teljes hiánya ugyanakkor figyelemreméltó, magyarázatként erre az szolgálhat, hogy ezen országok termékei leginkább a belföldi piacaikra fókuszálnak, s az árérzékeny külföldi fogyasztók elérése nem jelent prioritást. A termékcsoportokat tekintve az elérhető kínálatban a feldolgozott termékek (elsősorban sajtok és húskészítmények) jelentősen felülreprezentáltak, míg a friss termékek (zöldség-gyümölcs, friss hús) marginális szerepet töltenek be, vagy egyáltalán nem is jelennek meg. Itt elsősorban logisztikai magyarázat szolgálhat indokként: a friss földrajzi árujelzős termékek a romlandóságuk miatti addicionális költségeiknek köszönhetően nem igazán meghatározóak a diszkontok számára.

Ami a fogyasztói árakban realizálható prémiumot illeti, az árérzékeny fogyasztók elérésére nagy hangsúlyt fektető diszkontok esetében az átlagos árprémium figyelemre méltóan nagy (átlagosan 43\%), ami azt jelzi, hogy a magyar piacon is létezik a földrajzi árujelzővel ellátott termékek esetében egy érzékelhető árprémium. Az egyes diszkontok közötti különbség jelentősnek mondható, továbbá figyelemre méltó, hogy a földrajzi árujelzős kínálatában is a leginkább sajátmárkás termékeit forgalmazó Penny Market és Lidl esetében magasabb, mint a felerészt kereskedelmi márkákat is kínáló Aldinál. A felmérésünk alapján ugyanakkor nem állapítható meg egyértelmü összefüggés, hogy az OEM vagy az OFJ termékek esetében magasabb az árprémium. A származási ország 
és az árprémium közötti kapcsolatot vizsgálva kiemelhető, hogy amíg a legtöbb ország esetében $45-55 \%$ a felár, addig a legjelentősebb exportáló Olaszország termékeinek az árprémiuma a legalacsonyabb (19\%). Ez egyben azt is jelenti, hogy az olasz termékek helyettesítőinek árszínvonala közelíti meg leginkább azokat, s az olasz földrajzi árujelzős termékek kénytelenek a legnagyobb árharcba bocsátkozni. Ezzel összecseng továbbá az is, hogy a leginkább Olaszországból érkező földrajzi árujelzős sajtok esetében az egyik legalacsonyabb a termékcsoportonkénti átlagos árprémium, míg az alacsonyabb feldolgozottsági szintű (bár kevésbé elérhető) zöldség-gyümölcsök esetében ugyanez az érték jóval magasabb, a legjelentősebb felárat pedig a füszerek realizálták az eredményeink szerint.

A fenti eredmények értelmezésekor fontos figyelembe venni a tanulmány korlátait. $\mathrm{Az}$ élelmiszerdiszkontokon végzett felmérés ugyan jól jellemzi a legfontosabb trendeket, ugyanakkor az nem tekinthető reprezentatívnak az egész élelmiszer-kiskereskedelem tekintetében. A diszkontokban mért piacmérettel és árprémiummal valószínúleg egy megfelelő alsó becslést tudunk adni mindkét vizsgált ismérv esetében, hiszen egy jóval nagyobb kínálattal rendelkező és/vagy élelmiszer különlegességekre (is) fókuszáló élelmiszer-kiskereskedelmi egység kínálatában a földrajzi árujelzős termékek részesedése és árprémiuma is jóval nagyobb lehet. Ezért a téma további vizsgálatokat igényel, akár más típusú boltok (pl. hipermarketek, online webáruházak) akár más országok diszkontjai tekintetében, ahhoz hogy átfogó képet kaphassunk a földrajzi árujelzőkkel ellátott élelmiszerek piacáról.

\section{5. ÖSSZEFOGLALÁs - SUMMARY}

Ugyan a földrajzi árujelzős termékek kiemelt szerepet töltenek be az Európai Unió élelmiszereket érintő minőségpolitikájában és egyúttal a nemzetközi kereskedelmi megállapodásaiban, az ágazat átfogó elemzéséhez szükséges adatok nem állnak rendelkezésre. A földrajzi árujelzős élelmiszerek magyarországi szerepének vizsgálatához elérhető gazdasági adatok szintén korlátozottak, ezért a tanulmány empirikus adatgyüjtésre alapozva, a magyarországi élelmiszerdiszkontok példáján keresztül alulról próbálja becsülni az ágazat piacméretét és a fogyasztói árakon mért árprémiumát.

A három Magyarországon működő élelmiszerdiszkont egy-egy budapesti üzletében tizenkét hónapon keresztül folytatott próbavásárlásokkal 816 megfigyelést tartalmazó adatbázist hoztunk létre. Ennek elemzése alapján megállapítható, hogy a diszkontokban elérhető földrajzi árujelzős élelmiszerek döntő többsége import (leginkább olasz), a legtöbb termék az adott diszkont sajátmárkás terméke, továbbá leginkább a feldolgozott termékek (sajt és húskészítmények) dominálnak.

A földrajzi árujelzős termékek legközelebbi helyettesítő termékeikhez képest mért átlagos árprémiuma 43\%, ami különösen annak fényében jelentős, hogy a diszkontok hagyományosan leginkább az árérzékeny fogyasztókat célozzák meg. A legalacsonyabb árprémiummal az Olaszországból érkező, továbbá a magasabb feldolgozottsági szintű termékek rendelkeztek, ami egyben azt is jelenti, hogy ezeknek a termékeknek kell a legnagyobb árversenybe bocsátkozniuk.

Összességében a tanulmányunk alapján megállapítható, hogy a földrajzi árujelzős termékek száma a magyar élelmiszerdiszkontok kínálatában meglehetősen kevés, ugyanakkor jellemzően jelentős árprémiummal rendelkeznek. Mindezek alapján egy alsó becslést tudtunk adni ezeknek a termékeknek a magyarországi piacméretére és árprémiumára, ami várhatóan az élelmiszer-kiskereskedelem kevésbé árérzékeny fogyasztóit is megcélzó élelmiszerláncok esetében ennél magasabb lehet, melynek vizsgálata további kutatásokat igényel. 


\section{KöSZÖNETNYILVÁNÍTÁS -}

\section{ACKNOWLEDGEMENT}

A tanulmány a Bolyai János Kutatási Ösztöndíj támogatásával készült.

$\mathrm{Az}$ Innovációs és Technológiai Minisztérium ÚNKP-19-4-BCE-01 és ÚNKP-19-3I-BCE-134 kódszámú Új Nemzeti Kiválóság Programjának szakmai támogatásával készült.

A publikációhoz tartozó kutatások elvégzését és a publikáció elkészítését az NKFIH FK12480o és PD124791 „Az élelmiszer minőségi rendszerek és rövid élelmiszer ellátási láncok gazdasági és társadalmi hatásai Magyarországon” címú pályázat támogatta.

A szerzők továbbá köszönetüket szeretnék kifejezni Szekeres Kingának az adatfelvételben nyújtott segítségért.

\section{IRODALOMJEGYZÉK - REFERENCES}

Agrárminisztérium: Földrajzi Árujelzők Program. 2019. http://gi.gov.hu/ eredetvedelmi-program/ (Letöltés dátuma: 2019.08.12.)

AND International.: Value of Production of Agricultural Products and Foodstuffs, Wines, Aromatised Wines and Spirits Protected by a Geographical Indication (GI). https://ec.europa.eu/agriculture/ sites/agriculture/files/externalstudies/2012/value-gi/final-report_ en.pdf (Letöltés dátuma: 2019.08.12.)

Aprile, M. C. - Caputo, V. - Nayga Jr, R. M.: Consumers' Valuation of Food Quality Labels: The Case of the European Geographic Indication and Organic Farming Labels. International Journal of Consumer Studies. 2012. 36 (2) 158-165. DOI: http://dx.doi.org/10.1111/j.14706431.2011.01092.x

Aprile, M. C. - Gallina, G.: Quality Perception Using Signals on Food Labels: An Analysis on Italian Consumers. Paper Presented at the 18th Annual IAMA Symposium. Monterey, California, USA. 2018.
Arfini, F. - Capelli, M. G.: The Resilient Character of PDO/PGI Products in Dynamic Food Markets. St. Louis: Federal Reserve Bank of St Louis. 2009.

Belletti, G. - Burgassi, T. - Manco, E. - Marescotti, A. - Pacciani, A. - Scaramuzzi, S.: The Roles of Geographical Indications in the Internationalisation Process of Agri-Food Products. In: Canavari, M. - Cantore, N. - Castellini, A. - Pignatti, E. - Spadoni, R. (Eds.), International marketing and trade of quality food products (201-221): Wageningen Academic Publishers. 2009.

Bonnet, C. - Simioni, M.: Assessing Consumer Response to Protected Designation of Origin Labelling: A Mixed Multinomial Logit Approach Céline Bonnet. European Review of Agricultural Economics. 2001. 28 (4) 433-449. DOI: https://doi.org/10.1093/erae/28.4.433

Bryła, P.: The Perception of EU Quality Signs for Origin and Organic Food Products Among Polish Consumers. Quality Assurance and Safety of Crops \& Foods. 2017. 9 (3) 345-355. DOI: http://dx.doi. org/10.3920/QAS2016.1038

Engelhardt, T.: Geographical Indications Under Recent EU Trade Agreements. Iic-International Review of Intellectual Property and Competition Law. 2015. 46 (7) 781-818. DOI: http://dx.doi. org/10.1007/s40319-015-0391-3

Európai Bizottság: DOOR adatbázis. 2019. http://ec.europa.eu/agriculture/quality/ door/list.html?locale=hu (Letöltés dátuma: 2019.08.12.)

Fotopoulos, C. - Krystallis, A. Anastasios, P.: Portrait Value Questionnaire's (PVQ) Usefulness in Explaining Quality Food-Related Consumer Behavior. British Food Journal. 2011. 113 (2-3) 248-279. DOI: http:// dx.doi.org/10.1108/00070701111105330

Galli, F. - Carbone, A. - Caswell, J. A. - Sorrentino, A.: A Multi-Criteria Approach to Assessing Pdos/Pgis: An Italian Pilot Study. International Journal on Food System Dynamics. 2011. 2 (3) 219-236. DOI: https://doi.org/10.18461/ ijfsd.v2i3.233 
Geppert, M. - Williams, K. - Wortmann, M.: Micro-Political Game Playing in Lidl: A Comparison of Store-Level Employment Relations. European Journal of Industrial Relations. 2015. 21 (3) 241-257. DOI: http://dx.doi. org/10.1177/0959680114544015

Gijsbrechts, E. - Campo, K. - Vroegrijk, M.: Save or (over-)spend? The Impact of Hard-Discounter Shopping on Consumers' Grocery Outlay. International Journal of Research in Marketing. 2018. 35 (2) 270288. DOI: http://dx.doi.org/10.1016/j. ijresmar.2018.01.004

Groot, E. - Albisu, L. M.: Maxdiff Approaches for PDO "Calanda" Peaches (Spain). Paper presented at the 113th EAAE Seminar. Chania, Greece. 2009.

Hökelekli, G. - Lamey, L. - Verboven, F.: The Battle of Traditional Retailers Versus Discounters: The Role of PL Tiers. Journal of Retailing and Consumer Services. 2017. 39 11-22. DOI: http://dx.doi. org/10.1016/j.jretconser.2017.06.011

Jámbor, A. - Török, Á.: A regionális kereskedelmi egyezmények létrejöttét meghatározó tényezők. Közgazdasági Szemle. 2019. 65 (4) 418-433. DOI: https://doi.org/10.18414/KSZ.2019.4.418

Larson, R. B.: Profiling Prospective PrivateLabel Buyers. International Review of Retail, Distribution and Consumer Research. 2018. 28 (5) 516-530. DOI: http://dx.doi.org/10.108o/o9593969.201 8.1525757

Leufkens, D.: EU's Regulation of Geographical Indications and Their Effects on Trade Flows. German Journal of Agricultural Economics. 2017. 66 (4) 223233. DOI: http://dx.doi.org/10.22004/ ag.econ.303549

Liu, C.-H. S. - Su, C.-S. - Gan, B. - Chou, S.-F.: Effective Restaurant Rating Scale Development and a Mystery Shopper Evaluation Approach. International Journal of Hospitality Management. 2014. 43 53-64. DOI: http://dx.doi. org/10.1016/j.ijhm.2014.08.002
Liu, Y. - Chen, X. - Rabinowitz, A. N.: The Role of Retail Market Power and State Regulations in the Heterogeneity of Farm-Retail Price Transmission of Private Label and Branded Products. Agricultural Economics (United Kingdom). 2019. 50 (1) 91-99. DOI: http://dx.doi.org/10.1111/ agec. 12468

London Economics: Evaluation of the CAP Policy on Protected Designations of Origin (PDO) and Protected Geographical Indications (PGI). 2008.

Menapace, L. - Colson, G. - Grebitus, C. - Facendola, M.: Consumer Preferences for Extra Virgin Olive Oil With Country-OfOrigin and Geographical Indication Labels in Canada. St. Louis: Federal Reserve Bank of St Louis. 2008.

Monier-Dilhan, S.: Food Labels: Consumer's Information or Consumer's Confusion. OCL - Oilseeds and Fats, Crops and Lipids. 2018. 25 (2) DOI: http://dx.doi. org/10.1051/ocl/2018009

Neumeier, S.: Regional Accessibility of Supermarkets and Discounters in Germany - A Quantitative Assessment. Landbauforschung Volkenrode. 2015. 65 (1) 29-46. DOI: http://dx.doi. org/10.3220/LBF1439880683000

Sahelices, A. - Mesias, F. J. - Escribano, M. - Gaspar, P. - Elghannam, A.: Are Quality Regulations Displacing Pdos? A Choice Experiment Study on Iberian Meat Products in Spain. Italian Journal of Animal Science. 2017. 16 (1) 9-13. DOI: http://dx.doi. org/10.1080/1828051x.2016.1266704

Śmigielska, G. - Stefańska, M.: Innovative Positioning as a Marketing Tool of Retailers on the Food Market. Entrepreneurial Business and Economics Review. 2017. 5 (1) 77-90. DOI: http:// dx.doi.org/10.15678/EBER.2017.050105

Tibério, L. - Francisco, D.: Agri-food Traditional Products: From Certification to the Market - Portuguese Recent Evolution. Regional Science Inquiry. 2012. 4 (2) $57-86$. 
Török, Á.: A HíR védjegy ismertsége és beágyazódottsága a magyar fogyasztók körében. Táplálkozásmarketing. 2019. 6 (1) 81-97. DOI: http://dx.doi.org/10.20494/ $\mathrm{tm} / 6 / 1 / 6$

Török, Á. - Moir, H. V. J.: The Market Size for GI Food Products-Evidence from the Empirical Economic Literature. Studies in Agricultural Economics. 2018a. 120 (13162018-4981) 134-142.

Török, Á. - Moir, H. V. J.: Understanding the Real-World Impact of Gis: A Critical Review of the Empirical Economic Literature. ANU Centre for European Studies Briefing Paper Series. Jean Monnet Paper. 2018b. 9 (3) 1-67. https:// politicsir.cass.anu.edu.au/centres/ces/ research/publications/understandingreal-world-impact-gis-critical-reviewempirical-economic (Letöltés dátuma: 2019.08.12.)

Trade Magazin: FMCG Kereskedelmi Toplista. 2019. https://trademagazin. hu/hu/megjelent-az-fmcg-piac-2018evi-kereskedelmi-toplistaja/ (Letöltés dátuma: 2019.08.12.)

Urbano, B. - González-Andrés, F. Casquero, P.: Market Research for the Optimization of the Consumers Response to the Recent Award of a Protected Geographical Indication to a Local Product, Beans from "La BañezaLeón” (Spain). Journal of International Food \& Agribusiness Marketing. 2008. 20 (2) 7-32. DOI: http://dx.doi. org/10.1080/08974430802186076
Vecchio, R. - Annunziata, A.: The Role Of PDO/PGI Labelling in Italian Consumers' Food Choices. Agricultural Economics Review. 2011. 12 (2) 80-98. DOI: http:// dx.doi.org/10.22004/ag.econ.178224

von der Leyen, U.: Mission Letter for the Commissioner-Designate for Agriculture. 2019. https://ec.europa.eu/commission/ sites/beta-political/files/mission-letterjanusz-wojciechowski_en.pdf (Letöltés dátuma: 2019.10.12.)

Willems, K. - Leroi-Werelds, S. Swinnen, G.: The Impact of Customer Value Types on Customer Outcomes for Different Retail Formats. Journal of Service Management. 2016. 27 (4) 591618. DOI: http://dx.doi.org/10.1108/ JOSM-11-2015-0364

Yaoyuneyong, G. - Whaley, J. E. Butler, R. A. - Williams, J. A. - Jordan, K. L. - Hunt, L.: Resort Mystery Shopping: A Case Study of Hotel Service. Journal of Quality Assurance in Hospitality and Tourism. 2018. 19 (3) 358-386. DOI: http://dx.doi. org/10.1080/1528008X.2017.1418702

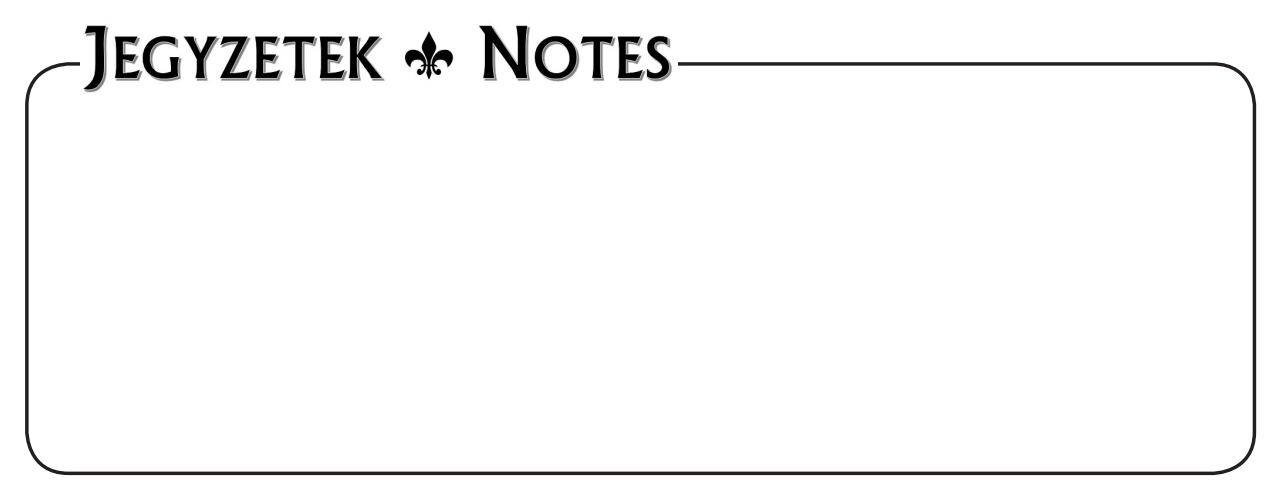

